\title{
Daily Drinking Patterns and Drinking Response to Angiotensin II in Young and Adult Budgerigars Melopsittacus undulatus
}

\author{
Yoko Kasuya*, Yuji Okawara, Kaoru Seki \\ and Hideshi Kobayashi
}

\begin{abstract}
Young (2 to 3 months old) and adult (more than 8 months old) Budgerigars (Melopsittacus undulatus) were purchased from a pet shop on April 5 and May 5, 1984, respectively. The daily water intake of both groups of budgerigars was observed for 13 to 14 months following the date of purchase and an examination was made of the dipsogenic action of angiotensin II (AII) on each group.

1. A peak in drinking activity was observed $1 \mathrm{hr}$ before and $1 \mathrm{hr}$ after the light was turned off at 2 weeks and 6 days following purchase in the young and adult specimens, respectively. However, after 4 to 5 months following purchase, two peaks in the drinking patterns could be observed in both groups: one soon after turning on the light and the other, $1 \mathrm{hr}$ before turning off the light. These drinking peaks were more prominent in the young than in the adult Budgerigars. They became less evident in June, 1985 in both groups.

2. No significant correlation was found between daily drinking patterns and changes in daily humidity.

3. The mean percentage of the number of birds drinking per hour in the daytime was 38.9 (young) and 14.3 (adults) at 2 weeks and 1.5 months following purchase, respectively, indicating that young Budgerigars drink once every 2 to $3 \mathrm{hrs}$ and adult once every $7 \mathrm{hrs}$. Thereafter, the percentage increased beyond 50 in both groups, indicating that all the birds drink at relatively short intervals (about once every $2 \mathrm{hrs}$ ). The percentage was always higher in the young groups, meaning that the young birds drank at shorter intervals.

4. The mean amount of daily water intake was 1 to $2 \mathrm{ml} /$ bird at 2 weeks and 1.5 months after purchase in young and adult birds, respectively, and increased gradually to 3 to $3.3 \mathrm{ml} / \mathrm{bird}$ at about 7 months (November, 1984) and 10 months (March, 1985), respectively. This increased level continued up to June 11,1985 in the young. In the adults, water intake decreased from March to about June, 1985. The mean amount of daily water intake was always greater in the young.

5. A significant correlation was found between the mean amount of daily water intake and mean daily humidity in both groups.

6. The percentage of water ingested in the day to the total daily amount was less than that drunk at night at 2 weeks and 1.5 months in the young and adult groups, respectively, but thereafter this tendency was reversed. In any one month, the percentage in the young always exceeded that in the adults.

7. Following a single intraperitoneal injection of $10 \mu \mathrm{g} / 100 \mathrm{~g}$ of $\mathrm{AII}$, more than $50-100 \%$ of the young responded by drinking, but only 0-71.4\% (usually $12-40 \%$ ) of the adults did so. AII was more dipsogenic in the young than in the adult birds.
\end{abstract}

Received 17 December 1986

Department of Biology, Faculty of Science, Toho University, Funabashi, Chiba 274, Japan.

* Present address: Life Science Institute, Sophia University, 7-1, Kioicho, Chiyoda-ku, Tokyo 102, Japan. 


\section{Introduction}

Daily drinking patterns have been extensively investigated mostly in mammals, and two peaks have been found in the marmoset (Saito et al. 1983) and IVCS mouse (Saito \& Takahashi 1979, Saito et al. 1980, 1982, 1983). However, only a limited number of studies have been conducted on the daily drinking patterns of birds. Fisher et al. (1972) investigated these patterns in 24 species of Australian birds in the field and found the Budgerigar (Melopsittacus undulatus) living in the field to have a pattern with one peak in the morning. Our data presented in a previous paper differ from this: Budgerigars kept in an animal room showed a daily drinking pattern with one peak in the evening. They investigated native birds whereas our birds were obtained from a commercial source and maintained in an animal room. Differences in food, age, temperature and humidity may also account for the discrepancy.

Seasonal environmental changes have been reported to affect the drinking patterns of the Bourke Parrot, Neopsephotus bourki: they were noted to drink before sunrise and after sunset but not to drink in the daytime during a southern hot period (summer) between September and March (Fisher et al. 1972). However, they drank throughout the daytime in August, with two peaks always in evidence (Davies 1972).

In the present study, daily drinking patterns were examined throughout a period of one year, using young and adult Budgerigars. Their water intake was analyzed with respect to age, photoperiod and humidity. An investigation was also made to determine any differences in dipsogenic response to angiotensin II (AII) according to age and the particular month of the year, since young Budgerigars were initially noted to drink more water than adult specimens in a day. There was also the desire to find out why budgerigars at the time of a previous study did not respond to AII by drinking (Koba-yashi et al. 1979), but did so later (Kasuya et al. 1985).

\section{Materials and Methods}

Young male Budgerigars (Melopsittacus undulatus) with pink cere ( 2 to 3 months of age) and adult male budgerigars with blue cere (more than 8 months of age) were purchased April 5 and May 5,1984 , respectively, from a commercial supplier. The young and adult Budgerigars were green and of mixed color, respectively. They were kept in a room maintained at $23 \pm 2^{\circ} \mathrm{C}$ under a fixed regime of $12 \mathrm{hr}$ light (07:00-19:00) and $12 \mathrm{hr}$ darkness. Light was supplied by two overhead fluorescent tubes. Each bird was kept in an individual cage $[30 \mathrm{~cm}(\mathrm{D}) \times 15.5 \mathrm{~cm}(\mathrm{~W}) \times 22 \mathrm{~cm}(\mathrm{H})]$, and screened from each other by cardbord inserted between the cages. During the experimental period, water and dehusked millet grain, $11.0 \%$ water by weight, were available ad libitum. The birds learned to drink water from a small hole in the glass tube connected to an inverted $10 \mathrm{ml}$ graduated cylinder. This they did for more than about 1 week before the start of the experiments. Measurements of water intake were made by reading the scale of the cylinder to the nearest $0.05 \mathrm{ml}$ every $1 \mathrm{hr}$ during a photoperiod and 1 or several hrs before and after the light was turned on and off. The total amount of water consumed during a dark period was also recorded. All measurements 
were made 9 times over a period of 13 and 14 months in the young and adult Budgerigars, respectively. For the adult Budgerigars, only measurements of water intake in the daytime at $2 \mathrm{hr}$ intervals and body weight were made in May. The number of birds drinking water each hour in a day was expressed as the percentage of the total number of birds used. Since a Budgerigar generally drinks 1-3 ml/day (Kasuya et al. 1985), those consuming an amount in considerable excess of this (more than $10 \mathrm{ml} /$ day/bird) were excluded from the present study. In all, 12 young and 7 adult Budgerigars were used. Humidity was also measured every $1 \mathrm{hr}$ during the daytime and the daily humidity was taken as the mean hourly humidity.

In the AII experiments, 8 young and 7 adult Budgerigars were used. AII was dissolved in a $0.9 \%$ saline solution and injected intraperitoneally in the amount of $10 \mu \mathrm{g} / 100 \mathrm{~g}$ each time. The injected volume was always $0.05 \mathrm{ml}$ and all injections were carried out at either 10:00 or 13:00, since this difference in time had no significant effect on the amount of water intake (Kasuya et al. 1985). The control birds were injected with the same amount of saline solution at about the same time. Measurements were made $30 \mathrm{~min}$ following the injections.

Other experimental and statistical methods for data analysis are described as necessary.

\section{Results}

\section{Changes in body weight}

The initial body weight of the young birds averaged $33.9 \pm 1.0 \mathrm{~g}$ on April 18, 1984, and increased gradually to $40.5 \pm 1.6 \mathrm{~g}$ by 12 months (March 3, 1985) (Fig. 1).

The initial body weight of adult birds was $33.0 \pm 1.0 \mathrm{~g}$ on May 5,1984 , and increased rapidly to $42.2 \pm 3.8 \mathrm{~g}$ by June 26. It remained at this level until April 17, 1985 (Fig. 1).

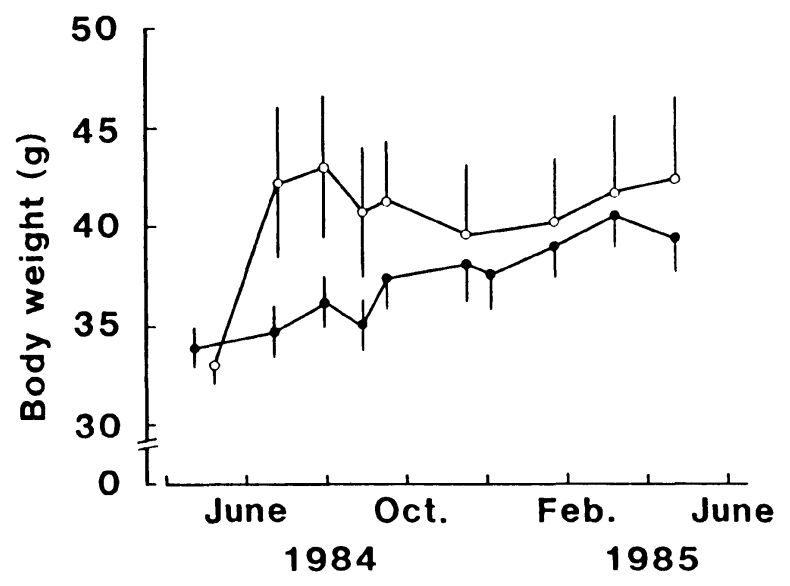

Fig. 1. Changes in body weight in young $(\bullet)(n=12)$ and adult Budgerigars $(O)(n=7)$. Values are presented as means with standard error (SE) 


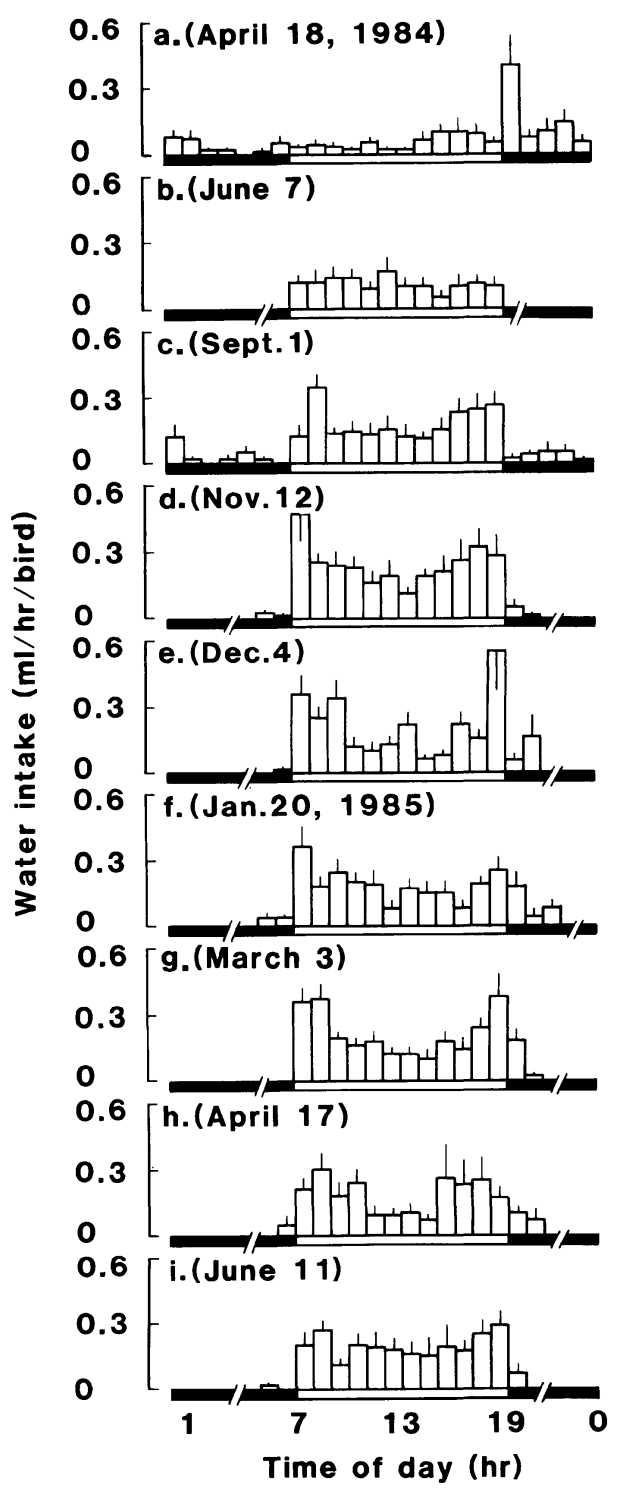

Fig. 2. Daily patterns of hourly water intake in young Budgerigars $(n=12)$ purchased on April 5. Each column shows mean with SE. Black underlines indicate hours of darkness.

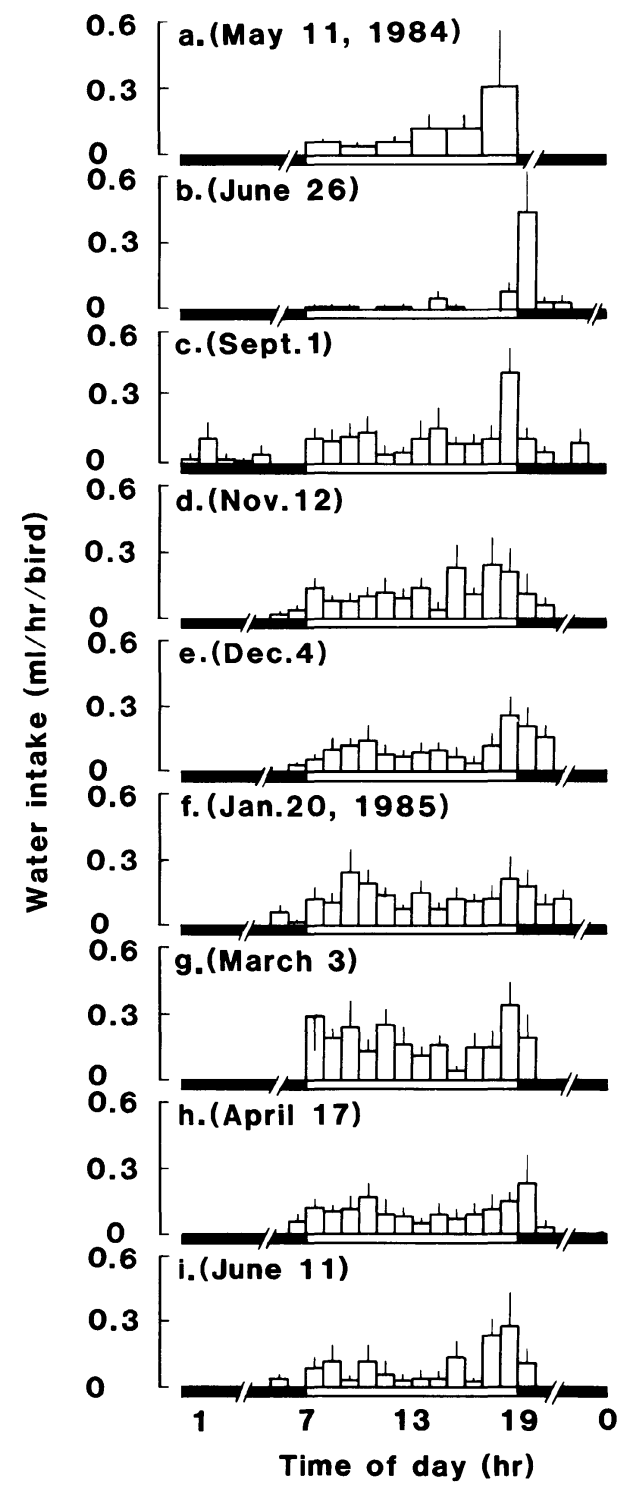

Fig. 3. Daily patterns of hourly water intake in adult Budgerigars $(n=7)$ purchased on May 5. Each column shows mean with SE. Black underlines indicate hours of darkness. Only on May 11 was water intake measured at $2 \mathrm{hr}$ intervals. 
2. Changes in daily drinking patterns

\section{(1) Young Budgerigars}

On April 18, 1984, 2 weeks following purchase, a peak of drinking activity was clearly observed $1 \mathrm{hr}$ after turning off the light (Fig. $2 \mathrm{a}$ ), but on June 7, at 2 months, drinking activity was essentially the same at any one hour (Fig. 2 b). On Sept. 1, at about 5 months, two drinking activity peaks were observed (Fig. 2c): one $2 \mathrm{hrs}$ after the light was turned on and the other, between 16:00-19:00. This two-peak drinking pattern continued until June 11, 1985 (Fig. 2i), although the peaks were not so evident. On April 17, 1985, one year following purchase, the birds showed a two-peak drinking pattern differing from that with only one peak observed one year before on April 18.

\section{(2) Adult Budgerigars}

On May 11, 1984, 6 days following purchase, only one peak was noted in the evening when drinking was measured at $2 \mathrm{hr}$ intervals (Fig. $3 \mathrm{a}$ ). On June 26, at 1.5 months, only one peak was evident $1 \mathrm{hr}$ after the light was turned off (Fig. $3 \mathrm{~b}$ ). The birds did not drink much water during the daytime. On Sept. 1, 1984, at about 4 months, the hourly drinking rate increased, givining rise to a clear peak $1 \mathrm{hr}$ before the light was turned off. The drinking rate was relatively high in the morning (Fig. 3c). Two peaks of drinking activity appeared to occur on Sept. 1. Thereafter, two peaks were noted both in the morning and evening, although they were not so apparent in April (Fig. 3h) and June (Fig. 3i), 1985.

\section{(3) Correlation between humidity and drinking patterns}

The relationship between changes in humidity and daily drinking patterns was examined in young and adult Budgerigars. For this purpose, correlation coefficients were calculated between the most, least hourly water intake in a day every month and the humidity when those water intakes occurred. No statistically significant correlation between humidity and water intake could be found in either young or adult Budgerigars. Thus daily drinking patterns may not be caused by daily changes of humidity.

\section{Changes in the mean percentage of the number of hourly drinking birds in the daytime}

\section{(1) Young Budgerigars}

As shown in Figure 4, the mean percentage of the number of hourly drinking birds in the daytime was $38.9 \pm 3.6$ ( 2 weeks after purchase, April 18, 1984). Drinking may have occurred once at comparatively long intervals of every $2-3 \mathrm{hr}$. The percentage then increased to $57.6 \pm 3.8$ (2 months, June 7, 1984). Thereafter, the percentages of the number of hourly drinking birds were between 66.0 and 81.9 until June 11, 1985. Thus, the birds came to drink once at relatively short intervals of 1-1.5 hr, beginning 5 months after purchase (Sept. 1, 1984). These percentages thus significantly increased rapidly from April 18 up to about Nov. 12, (analysis of variance of two-way layout without repetition ( $F=16.01, D f=8, P<0.05)$ and paired randomization test) followed by an increased level that continued until June 11, 1985. 


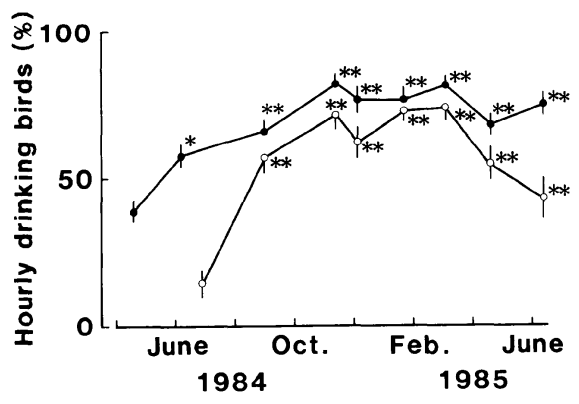

Fig. 4. Mean percentage of the number of hourly drinking birds to total birds for both young $(\bullet)(n=12)$ and adult specimens $(O)(n=7)$. Values are presented as means with SE. *, significant $(P<0.05)$ and $* *$, highly significant $(P<0.01)$ (paired randomization test), compared with initial values in each group.

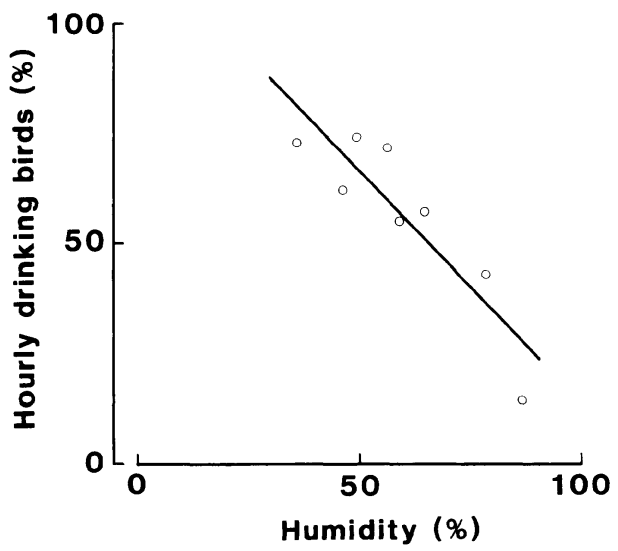

Fig. 5. Correlation between the mean percentage of the number of hourly drinking birds in the daytime and the mean hourly humidity in the daytime in adult Budgerigars. $Y=-1.06 X+119.01(P<0.01)$.

\section{(2) Adult Budgerigars}

The mean percentage of the number of hourly drinking birds in the daytime was only $14.3 \pm 4.7$ (1.5 months, June 26, 1984) suggesting drinking to occur at relatively long intervals of $7 \mathrm{hr}$ (Fig. 4). Later, the percentage became $57.1 \pm 5.6$ (4 months, Sept. 1, 1984), and further increased to $73.8 \pm$ 4.6 (10 months, March 3, 1985). The percentage decreased to $54.8 \pm 5.8$ (11 months, April 17, $1985)$ and $49.9 \pm 7.0$ (13 months, June 11, 1985). These data indicate that adult Budgerigars drank once at comparatively short intervals of 1-2 hr after Sept. 1, 1984. It is evident that the percentages significantly increased rapidly from June 26 to Nov.12 (analysis of variance of two-way layout without repetition ( $F=12.40, D f=7, P<0.005)$ and paired randomization test) (Fig. 4) and the increased level continued to March 3, and then decreased significantly toward June 26, 1985 (paired randomization test). The values were always less in adult than young Budgerigars (analysis of variance of two-way layout with repetition $(F=52.08, D f=1, P<0.002)$ ) (Fig. 4).

(3) Correlation between humidity and percentage of the number of birds drinking during the daytime

Statistical analysis was carried out to determine if a correlation existed between the mean hourly humidity of days on which water intake was measured and the mean percentage of the number of hourly drinking birds. No such correlation was found in young budgerigars, but it was highly significant in adult specimens (Fig. 5).

\section{Changes in daily water intake}

(1) Young Budgerigars 


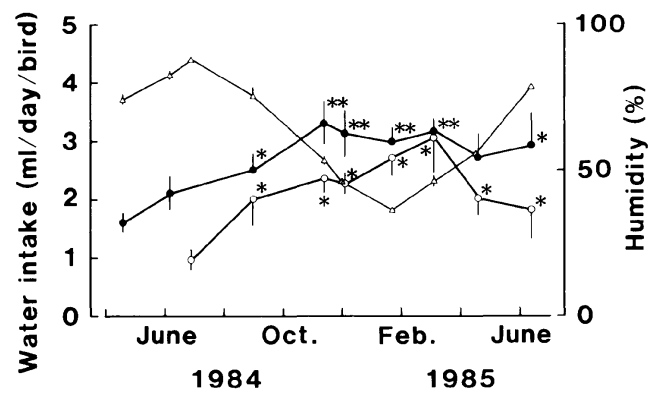

Fig. 6. Humidity $(\triangle)$, and amounts of daily water intake in young $(\bullet)(n=12)$ and adult Budgerigars $(\bigcirc)(n=7)$. Values are presented as means with $\mathrm{SE}$. *, significant $(P<0.05)$ and $* *$, highly significant $(P<0.01)$ (paired randomization test), compared with initial values.

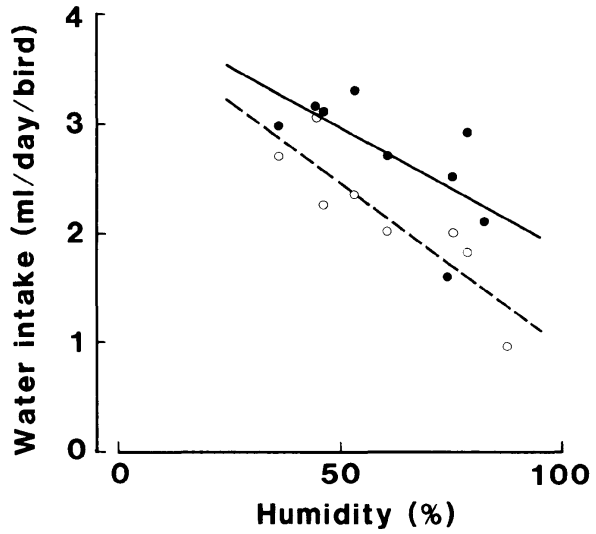

Fig. 7. Correlation between amount of daily water intake and mean daily humidity throughout the experimental period. In young Budgerigars $(\bullet$, solid line), $Y=$ $-0.02 X+4.08 \quad(P<0.05)$; in adult Budgerigars $(\bigcirc$, broken line), $Y=$ $-0.03 X+3.95(P<0.01)$.

Young budgerigars daily consumed $1.60 \pm 0.16 \mathrm{ml} /$ bird 2 weeks after purchase (April 18, 1984), and the amount significantly increased to $3.30 \pm 0.37 \mathrm{ml} /$ bird at 7 months (Nov. 12, 1984) (analysis of variance of two-way layout without repetition $(F=2.59, D f=8, P<0.05)$ and paired randomization test)(Fig. 6). The increased level continued until June 11, 1985.

\section{(2) Adult Budgerigars}

The daily amount in these specimens was $0.96 \pm 0.17 \mathrm{ml} /$ bird 1.5 months after purchase (June 26, 1984)(Fig. 6) and thereafter increased significantly to about $3 \mathrm{ml} /$ bird at about 10 months (March 3, 1985)(analysis of variance of two-way layout without repetition $(F=4.30, D f=7, P<$ 0.002 ) and paired randomization test) (Fig. 6). This was followed by a significant decrease up to about June 11, 1985 (paired randomization test). Water intake was always less in the adult specimens (analysis of variance of two-way layout with repetition $(F=12.90, D f=1, P<0.002)$ ) (Fig. 6).

(3) Correlation between humidity and amount of daily water intake

A significant correlation was observed between the mean daily humidity and mean daily water intake in both young $(\boldsymbol{P}<0.05)$ and adult Budgerigars $(\boldsymbol{P}<0.01)$ (Fig. 7). A comparison of the two lines in Figure 7 shows the adult specimens to be more sensitive to humidity.

5. Changes in the percentage of daytime water intake to total daily water intake

(1) Young Budgerigars 


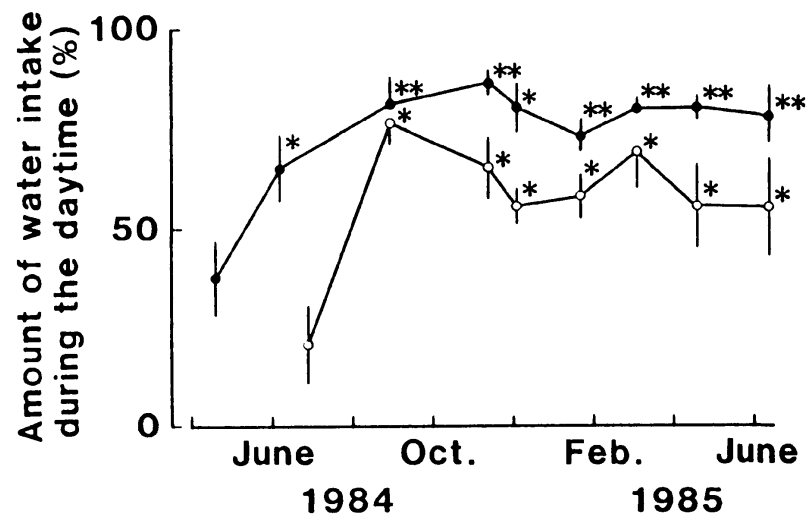

Fig. 8. Mean percentage of daytime water intake to total daily water intake in young $(\bullet)(n=12)$ and adult Budgerigars $(O)(\mathrm{n}=7)$. Values are presented as means with $\mathrm{SE} .{ }^{*}$, significant $(P<0.05)$ and $* *$, highly significant $(P<0.01)$ (paired randomization test), compared with initial values in each group.

The mean percentage of water drunk during the day (07:00-19:00) to total amount consumed per day is shown in Figure 8. Two weeks after purchase (April 18, 1984), this value was only 37.4 $\pm 9.4 \%$. After that, water intake in the daytime increased significantly up to about Sept. 1, 1984, (analysis of variance of two-way layout without repetition $(F=9.22, D f=8, P<0.002)$ and paired randomization test). The night and day drinking rates then became reversed so that $80 \%$ of their total daily water was consumed in the daytime (Fig. 8). The increased level of water intake continued until June 26, 1985.

\section{(2) Adult Budgerigars}

The mean percentage of water intake in the daytime to the total daily amount was 20.6 at 1.5 month following purchase (June 26, 1984), indicating daily water intake to occur mostly during the night. After that, the percentage increased markedly up to about Sept. 1 (76.6\%) (analysis of variance of two-way layout without repetition $(F=8.13, D f=7, P<0.002)$ and paired radomization test) (Fig. 8) and the increased level persisted until June 26, 1985. These observations show that during the period from 4 to 13 months following purchase (Sept. 1, 1984 to June 11, 1985), the birds drank slightly more in the daytime than at night (Fig. 8). The percentage was always less in adult specimens (analysis of variance of two-way layout with repetition $(F=37.10, D f=1, P<0.002)$ ) (Fig. 8).

\section{Changes in dipsogenic response to $A I I$}

From half to nearly all the young Budgerigars (generally 75-87\%) responded to a single intraperitoneal injection of AII by drinking within 30 min following the injection (Fig. 9).

In the adult specimens, $0-71.4 \%$ (usually $12-40 \%$ ) of the birds responded to AII by drinking 


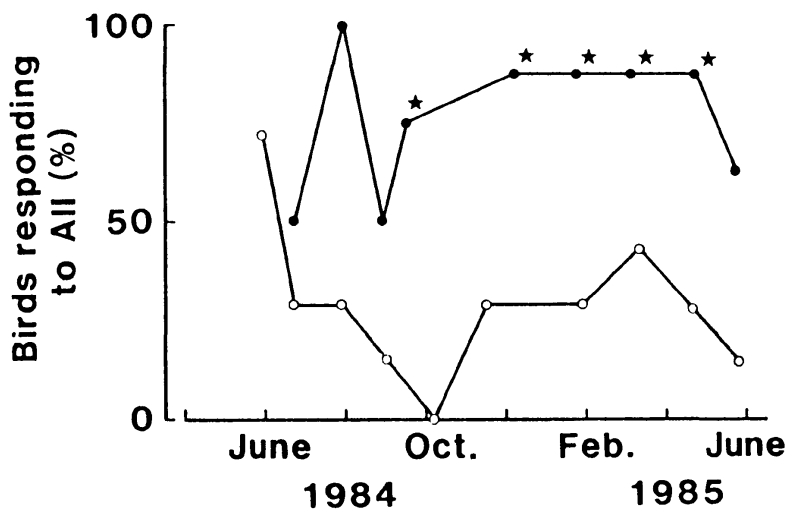

Fig. 9. Percentages of the number of birds responding to a single ip injection of $10 \mu \mathrm{g} / 100 \mathrm{~g}$ of AII within 30 min following injection in young $(\bullet)(n=12)$ and adult Budgerigars $(0)(n=7)$. , significant $(P<0.05)$, compared with adult Budgerigars ( $\mathrm{t}$-test or Cochran-Cox test).

during the period from June 26, 1984 to May 24, 1985. None of the birds responded to AII on Oct. 5, 1984 (Fig. 9). Adult Budgerigars were found significantly less responsive to AII (analysis of variance of two-way layout with repetition $(F=38.50, D f=1, P<0.002)$ and $t$-test or Cochran-Cox test) (Fig. 9).

\section{Discussion}

In a previous paper (Kasuya et al. 1985), we reported a daily drinking pattern with one peak in the evening 2 weeks following purchase in April, 1984, in young green male Budgerigars. In the present study, both young and adult birds showed a daily drinking pattern with one peak at 2 weeks and 6 days after purchase, respectively, and a two-peak drinking pattern at 4 to 5 months (Sept. 1, 1984). In the young birds, the two-peak drinking pattern was not detected on April 18 and June 7 , and in the adult birds, it was not detected on May 11 and June 26. This may be due in part to their drinking at night and consequently no peak would be observed in the morning. The stress caused by their transfer from a pet shop to the animal room at our laboratory may also have been a factor contributing to this drinking behavior, as well as the high humidity from April to June. The present data show a significant correlation between humidity and daily water intake in both young and adult Budgerigars. Changes in daily drinking patterns according to season have been suggested by Davies (1982) on the basis of observations in which the drinking activity of the Bourke Parrot (Neopsephotus bourki) in the field of Australia was noted to be high before sunrise and after sunset in the southern hot period (summer) from September to March (Fisher et al. 1972), and to persist throughout the daytime in August (Davies 1972).

In native Budgerigars living in the field of Australia, Fisher et al. (1972) found only a morning peak in daily drinking patterns during the southern hot period (summer). Serventy (1971) also 
noted only a morning peak in daily drinking patterns in the Budgerigar in the field of Australia. Wyndham (1980) also found that Budgerigars drink intermittently and at no specific time of the day in the field in eastern Australia. The disagreement between their and our data may possibly arise from differences in temperature, photoperiods, humidity and food.

The low percentage of hourly drinking birds and small amount of water intake during 4 to 5 months after purchase may have been caused by stress experienced by the birds on being transferred and high humidity, the same reasons already given for changes in daily drinking patterns. In addition, the high percentage of water intake at night during 4 to 5 months after purchase may also have resulted from transfer stress of birds, since rather stable levels were observed after that. The decrease in percentage of hourly drinking birds and amount of daily water intake in April and May in 1985 also seems due to high humidity.

We reported green Budgerigars to be insensitive to AII (Kobayashi et al. 1979). But in this and a previous study (Kasuya et al. 1985) both young and adult Budgerigars responded to AII (10 $\mu \mathrm{g} /$ $100 \mathrm{~g}$ ) by drinking, though the adult birds were less responsive. In October, 1984, no adult Budgerigars responded to AII. Kobayashi et al. (1979) may have encountered such a case. They reported that green Budgerigars did not respond to AII by drinking. The present data indicate daily water intake and the mean percentage of the number of hourly drinking birds in the daytime to always be greater in young than adult Budgerigars. These observations may be related in some way to the finding that dipsogenic response to AII is much stronger in young than adult Budgerigars.

In this study, adult Budgerigars (mixed-color) drank less water than young Budgerigars (green), and dipsogenic reaction to AII was always stronger in the young (green) than adult specimens (mixed-color). It seems that age more than body color may be a factor determining drinking behavior.

\section{Acknowledgements}

The authors would like to express their gratitude to Professor Susumu Ishii, Waseda University, for his valuable advice and to Mr. Takeo Karakida, Niigata University, for his helpful suggestions. This investigation was supported by Grant-in-Aid for Scientific Research from the Ministry of Education, Science and Culture of Japan.

\section{References}

Davies, S. J. J. F. 1972. Results of 40 hours' continuous watch at five waterpoints in an Australian desert. Emu 72: $8-12$.

Davies, S. J. J. F. 1982. Behavioural adaptations of birds to environments where evaporation is high and water is in short supply. Comp. Biochem. Physiol. 71A: 557-566.

Fisher, C. D., Lindgren, E. \& Dawson, W. R. 1972. Drinking patterns and behavior of Australian desert birds in relation to their ecology and abundance. The Condor 74: 111-136.

Kasuya, Y., Karakida, T., Okawara, Y., Yamaguchi, K. \& Kobayashi, H. 1985. Daily drinking patterns and plasma angiotensin II in the budgerigar (Melopsittacus undulatus) and the Japanese quail (Coturnix coturnix japonica). J. Yamashina Inst. Ornith. 17: 32-43.

Kobayashi, H., Uemura, H., Wada, M. \& Takei, Y. 1979. Ecological adaptation of angiotensin-induced thirst 
mechanism in tetrapods. Gen. Comp. Endocrinol. 38: 93-104.

Saito, T. R., Katsuyama, M., Murakoshi, H., Koide, M., Yamaguchi T. \& Takahashi, K.W. 1983. Patterns of drinking behavior in the common marmosets, Callithrix jaccus jaccus. Zool. Mag. 92: 216-218.

Saito, T. R., Katsuyama, M. \& Takahashi, K. W. 1980. Rhythms in drinking behavior in the mouse. Zool. Mag. 89: $312-316$.

Saito, T. R., Katsuyama, M. \& Takahashi, K. W. 1982. Diurnal rhythms in drinking behavior in polyuric IVCS mice. Zool. Mag. 91: 289-292.

Saito, T. R., Katsuyama, M. \& Takahashi, K. W. 1983. Rhythms in water drinking behavior during lactation in the mouse. Zool. Mag. 92: 412-415.

Saito, T. R. \& Takahashi, K. W. 1979. Structural outline of drinking behavior activity monitor using touch limit switch for small laboratory animals. Exp. Anim. 28: 405-407.

Serventy, D. L. 1971. Biology of desert birds. In: Avian Biology (Farner, D. S. \& King, J. R., eds.), pp. 287-339. Academic Press, New York.

Wyndham, E. 1980. Diurnal cycle, behaviour and social organization of the budgerigar Melopsittacus undulatus. Emu 80: 25-33.

\section{セキセイインコの若鳥と成鳥における 1 日の飲水パターンとアンギオテンシンへの反応性}

セキセイインコの若鳥 12 羽（2-3 ケ月令）と成鳥 7 羽（8 ケ月令以上）を，それぞれ 1984 年 4 月 5 日と 5 月 5 日に購入して, $12 \mathrm{~L} 12 \mathrm{D}$, 約 $23^{\circ} \mathrm{C} て ゙$ 飼育し, 13-14 ケ月にわたり, 各々 9 回飲水量を測定した。また, アンギオテンシン II に対する反応性を，若鳥 8 羽，成鳥 7 羽で調べた。

（1）購入 2 週間後の若鳥，また 6 日後の成鳥は，それぞれ，19:00の消灯前かその後にピークがある 1 峰 性の 1 日の飲水パターンを示した。しかし, 購入 4-5 ケ月以後（1984 年 9 月）の観察では, 雨者共に点灯 直後と消灯直前に飲水が多く，2峰性の飲水パターンを示した。2 峰性は若鳥の方が成鳥より明瞭であっ た。しかし，両者ともに1985年6月にはピークは低く，2峰性はあまり顕著でなくなった。

（2）1日の飲水量のパターンと，1日の湿度の変化との間には相関関係はみられなかった。

（3）昼間 1 時間当りに飲水をした鳥の数のパーセントの 1 日の平均值は, 若鳥では購入 2 週間後に $38.9 \%$ であり, 成鳥では購入 1.5 ケ月後に $14.3 \%$ であった。すなわち, 若鳥は尽間の 2-3 時間に 1 回の割 合で飲水を行い，成鳥では 7 時間に 1 回の割合で飲水をした。その後は，両者共に，平均值は $50 \%$ をこ， 飲水は約 2 時問に 1 回の割合で行われた。しかし, 若鳥の平均值は, 常に成鳥よりも大きかった。このこと は，若鳥は成鳥よりも飲水頻度が大きいことを示す。

（4）若鳥の 1 日の飲水量は, 購入 2 週間後（4月 18 日）では 1-2 ml であったが, その後次第に増し, 7 ケ月後（1984年11月）には約 $3.3 \mathrm{ml}$ に増え，この飲水量は翌年，1985 年 6 月まで続いた。成鳥では，購 入 1.5 ケ月後（6月 26 日）では約 $1 \mathrm{ml}$ であったが，その後増加し，約 10 ケ月後（1985 年 3 月）には $3 \mathrm{ml}$ となったが，その後減少し6月には約 $1.5 \mathrm{ml}$ となった。1 日の飲水量は，常に若鳥が成鳥よりも多かった。

（5）1日の総飲水量の平均值と 1 日の湿度の平均值との間には相関関係がみられた。

（6）購入 2 週間後の若鳥と 1.5 ケ月後の成鳥では，液間における飲水量は昼間のそれよりも多かった が，その後，それぞれ，その関係は逆になり，昼間に多く飲水するようになった。1日のうちで昼間に飲む 飲水量の割合は，若鳥の方が成鳥よりも常に多かった。

（7）アンギオテンシン II $(10 \mu \mathrm{g} / 100 \mathrm{~g})$ を腹腔内注射したところ，若鳥では注射の何れの月においても $50 \%$ 以上（通常約 80\%）の鳥が反応して飲水したが，成鳥では通常約 30\%の鳥しか反応しないし，10月 の注射では1 羽も反応しなかった。

（8）セキセイインコを購入し, 研究室の動物舎に移してから約 1 年間にみられた飲水量の諸変化及びア 
ンギオテンシン II に対する反応性の変化に関し，種々の点から検討を加えた。

糟谷洋子*, 大河原雄児, 関 薰, 小林英司：東邦大学理学部生物学教室. 画274 千葉県船橋市三山 2-2-1

* 現在は, 上智大学生命科学研究所. 102 東京都千代田区紀尾井町 7-1 